\title{
Museums in Myanmar: Brief History and Actual Perspectives
}

\author{
Nu Mra Zan
}

\begin{abstract}
The history of Myanmar museums from the earliest such as ancient palaces and Pitaka libraries, through museums established before independence such as Bagan Archaeological Museum, to the most recent-days is described. The establishment of the Ministry of Culture in 1952, 4 years after regaining independence, led to construction of the first National Museum (Yangon) and several other museums. Currently, Myanmar museums under the Ministry of Culture can be classified as national museums, archaeological museums, regional cultural museums, and memorial museums. Other kinds of museum are now appearing under other ministries and in the private sector in Myanmar. There is an urgent need for collaboration between these different museums to form a nation-wide museum organization, in order to work together for the improvement of Myanmar museums, and to facilitate international cooperation.
\end{abstract}

\section{Introduction}

The Cultural Policy of Myanmar aims to raise national prestige and integrity through the preservation and safeguarding of cultural heritage and national character. According to the Cultural Policy, the mission statement of the Ministry of Culture is to "Honor the State with Culture" (Department of Cultural Institute 2000: 8).

Myanmar has an abundant and diverse cultural heritage in both tangible and intangible forms. This heritage is mainly preserved in the National Museum (Yangon) and Bagan Archaeological Museum together with other regional cultural museums and other archaeological museums under the Ministry of Culture.

Museums under the Ministry of Culture can be classified as national museums, archaeological museums, regional cultural museums as ethnological museums, and memorial museums. Not only under the Ministry of Culture but also some religious museums, private museums, and historic houses under other institutions are undertaking the duties and tasks of preserving the cultural heritage of Myanmar.

N.M. Zan $(\bowtie)$

Department of Archaeology and National Museum, Ministry of Culture,

Office No 35, Nay Pyi Taw, Myanmar

e-mail: numra.museum@gmail.com 
Nowadays, other types of museum are appearing more frequently under other ministries and the private sector in Myanmar.

\section{History of Museum Establishment in Myanmar}

\subsection{Earliest Museums}

\subsubsection{Ancient Palaces and Pitaka Libraries}

The ancient palaces of successive periods and Pitaka libraries can be defined as the earliest museums of Myanmar. Arimaddanapura Zeyabon Palace in Bagan, Kamboza Thardi Palace in Bago (Fig. 1), Myanan Sankyaw Palace in Mandalay (Fig. 2), and Shwebonyadanar Palace in Shwebo (Fig. 3) are some examples while Bagan Pitaka Library of King Anawrahta and Chron-Kite Pitaka Library of Mrauk-U are other examples of the earliest museums, which are the only first-generation collection-centered type of museum.

\subsubsection{The First Museum: Phayre Museum}

After the end of the Second Anglo-Burmese War in 1852 came the colonial period in Myanmar, and a museum appeared honoring Sir Arthur Phayre, namely the Phayre Museum, based on the collection of Sir Arthur Phayre, Bago Division commissioner and owner of the collection (Min Naing 1978: 5).

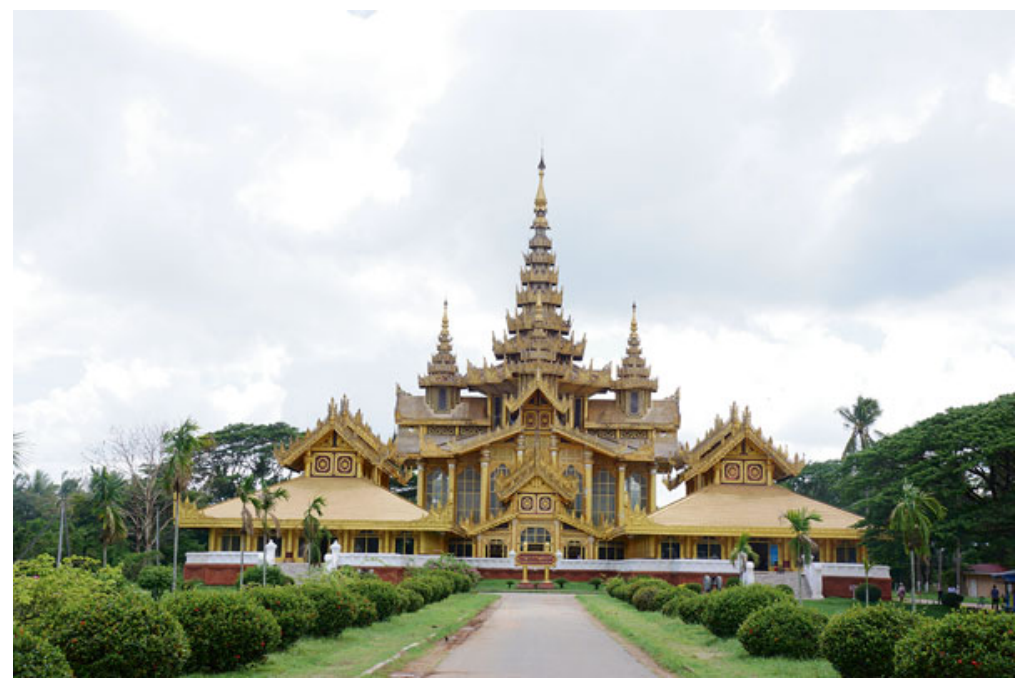

Fig. 1 Kamboza Thardi Palace in Bago 


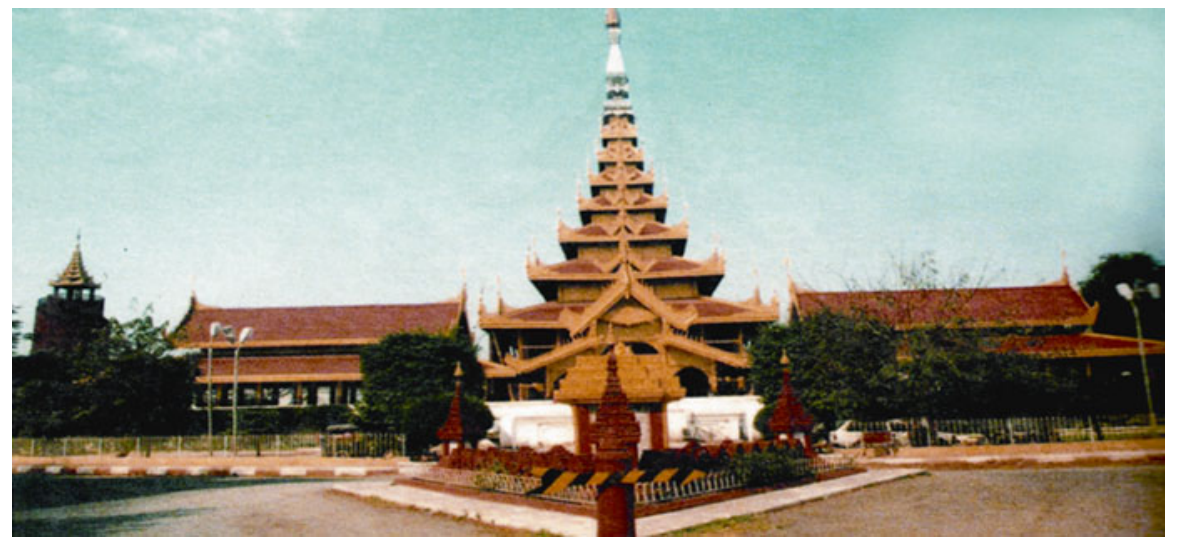

Fig. 2 Myanan Sankyaw Palace in Mandalay

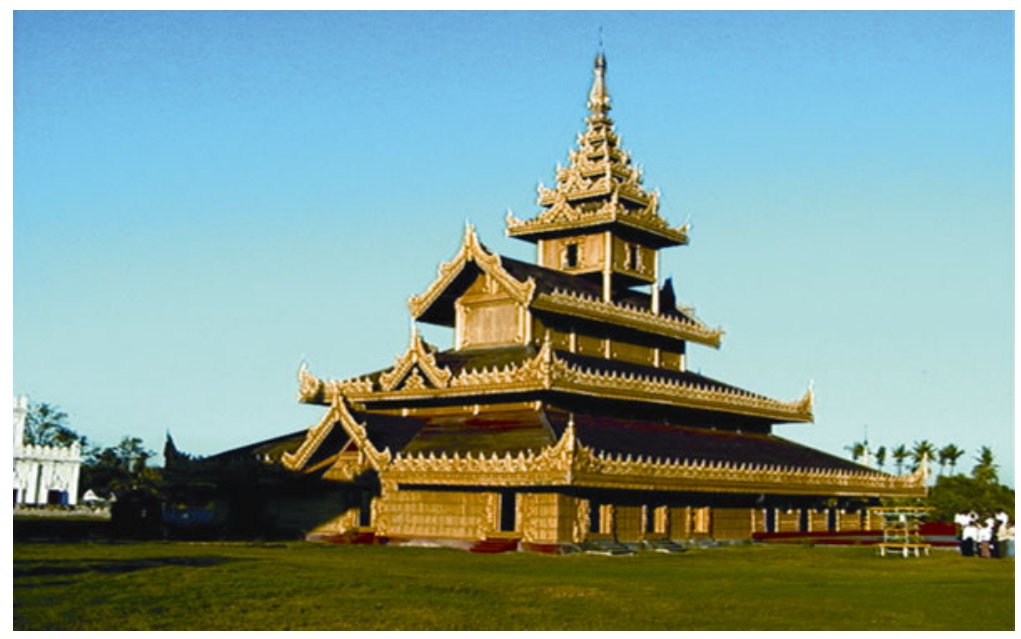

Fig. 3 Shwebonyadanar Palace in Shwebo

The Phayre Museum was built in the gardens of the Rangoon Agri-Horticultural Society in 1871, and it was later dismantled to make way for the Rangoon General Hospital (Taylor 1924:3). After dismantling it, a museum that could be converted into the Phayre Museum in Rangoon (now Yangon) did not appear till 1952 although it can be said that establishment of the Phayre Museum first shaped the Myanmar National Museum. 


\subsection{History of Museums Established in Myanmar Before Independence}

\subsubsection{Brief History of the Bagan Archaeological Museum}

Myanmar was annexed by the British in 1885 and before independence, very few site museums were established. Among them, Bagan Archaeological Museum was the first. The first Bagan Museum (Fig. 4 upper left) was established in 1903 near the famous Ananda Temple and was newly constructed in 1937-38.

After the 1940s, to avoid destruction in the Second World War, all artifacts of Bagan Museum were buried very safely in the earth. When Myanmar regained her independence, the Ministry of Culture, which was established in 1952, arranged to unearth the artifacts and reopened the museum to the public in 1954 (Min Naing 1978: 8, 9).

Museum collections increased year by year and a new octagonal-shaped museum building was built in 1979 (Fig. 4 upper right). As that building also became full of artifacts, the present big four-storied building was established in 1995 and opened to the public on April 17, 1998 (Fig. 4 lower) (Department of Archaeology and National Museum 1997: 2).
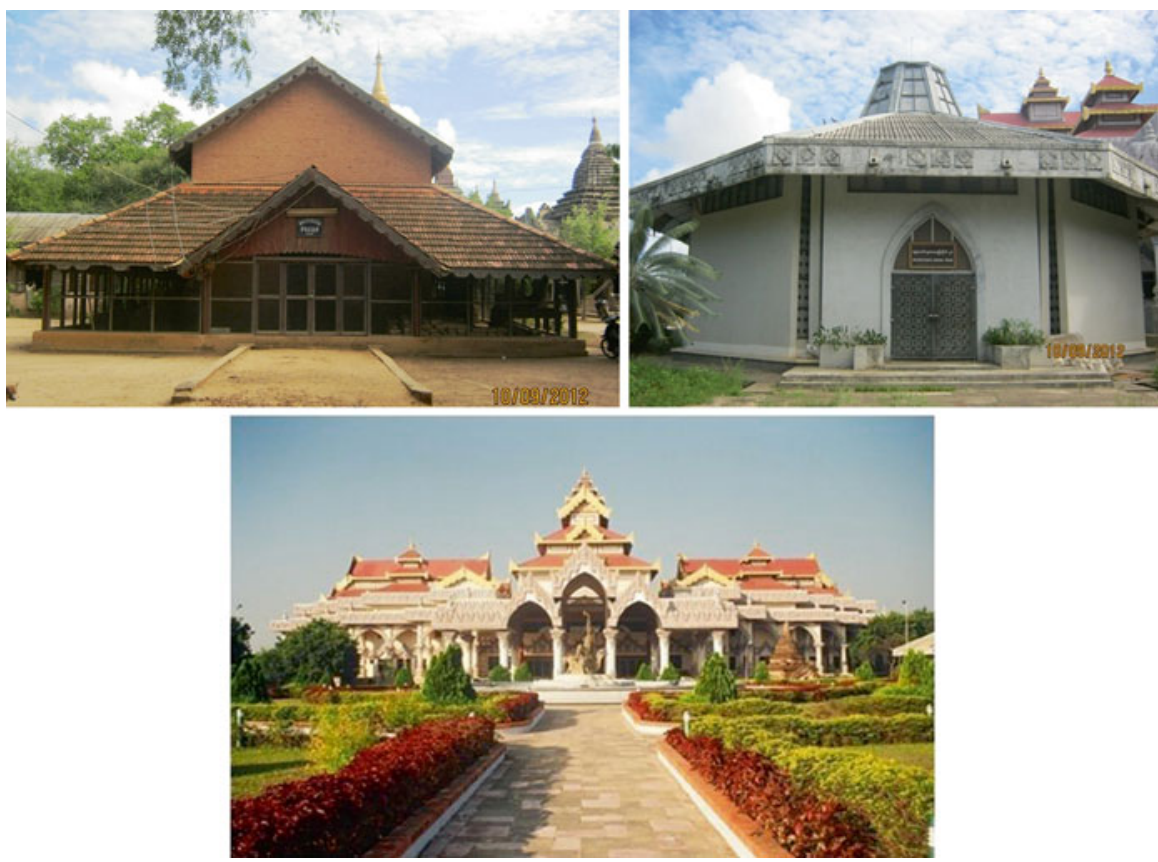

Fig. 4 Bagan Archaeological Museum: The first museum (now storage) (upper left); the second museum (now storage) (upper right); the present museum (lower) 


\subsubsection{Brief History of the Sri Ksetra Archaeological Museum}

One of the most important earliest museums of Myanmar, established in Hmawza Village in Pyay (Prome), was the Sri Ksetra Archaeological Museum. In the 1900s, the Epigraphy Department explored and collected antiquities within the area of Sri Ksetra and, to store them, a small building called Thayet Taw Museum was established near the ancient palace site of Sri Ksetra between 1907 and 1910. After it was burnt down in 1915, Kyaukka Thein was constructed as the first museum of Sri Ksetra in 1915.

The current museum building near Kyaukka Thein Museum and the Monastery Museum was built in 1960-1961 and opened to the public 1 year later (Min Naing 1978: 10).

\subsubsection{Brief History of Other Early Museums}

One of the earliest museums in Myanmar is Mrauk-U Archaeological Museum (Fig. 5) located in Mrauk-U, the last capital of Rakhine Kingdom and now an ancient city of Rakhine State, which was established in 1904. The museum is located just next to the site of the House-of-Jewels on the terrace of the Mrauk-U Palace site (Min Naing 1978: 11).

Another early museum was established in Shwebo in 1904. At first, the Indian government provided subsidies but later it was difficult for it to stand permanently. It has now been substituted by the Shwebonyadana Palace Museum, built in 1994

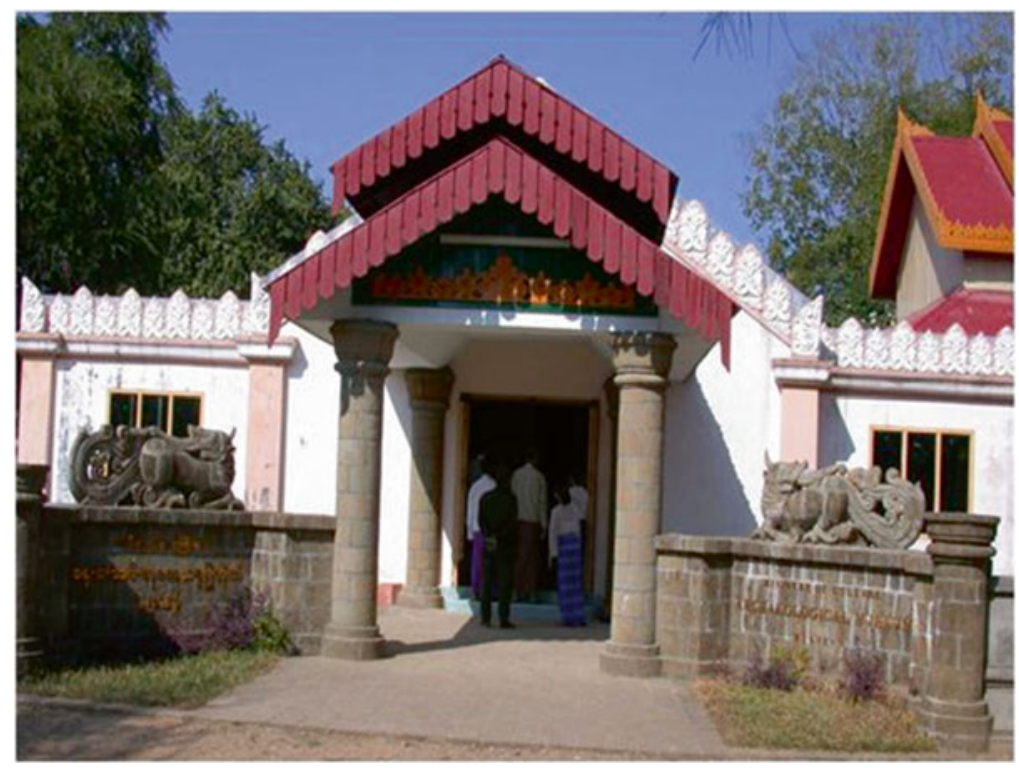

Fig. 5 Mrauk-U Archaeological Museum 
and opened in 1999. Another early museum was located in Mandalay. It was established in 1905 in Mandalay Palace City and called the Mandalay Palace Museum. It is totally different from the present Mandalay Palace Museum, because its collection, comprising objects related to the Palace and various other artifacts, was destroyed by fire because of bombing during the Second World War (Min Naing 1978: 11-13). Today, there is the Myanansankyaw Palace Museum, which was opened to the public in 1996.

Not only were these regional museums opened and governed by the government, but religious museums were also opened by the trustee boards of the pagodas. Among them, the most famous one is the Shwedagon Pagoda Museum whose establishment started from around the 1900s. The present-day Shwedagon Pagoda Museum building was constructed in 1992 (Min Naing 1978: 14).

\subsection{History of Museums Established in Myanmar After Independence}

Four years after regaining independence, the establishment of the Ministry of Culture in Myanmar in 1952 saw the birth of the first national museum in Myanmar (Min Naing 1978: 5).

\subsubsection{Background History of the National Museum (Yangon)}

After regaining independence, the National Museum was opened at the Jubilee Hall Building on the Shwedagon Pagoda Road in June 1952. The collection gradually increased and in 1957, the Royal Lion Throne was moved from the President's Residence to the National Museum and exhibited there. In 1968, it moved to a building in Pansodan Street, which was a former private bank, and it was opened to the public on February 8, 1970 with six exhibition rooms.

Twenty-five years later, the National Museum moved to its present location on 66/74 Pyay Road, Dagon Township in Yangon, and was opened to the public on September 18th, 1996 (Fig. 6).

\subsubsection{Brief History of Regional Cultural Museums in States and Divisions}

According to the policy guideline of the Ministry of Culture, a project to establish regional museums and libraries in some areas of Myanmar was conducted in 1955. After Cultural Councils were organized in respective regions, state or divisional museums appeared in Mandalay for the Mandalay Division (Fig. 7), Kyauk Pyu for the Rakhine (Arakan) Division and Mawlamyaing for the Taninthayi (Tanessarim) Division in 1955. In 1964, these museums were governed by the Ministry of Culture and Rakhine State Museum moved to Sittwe (Akyab), the capital city (Fig. 8). 


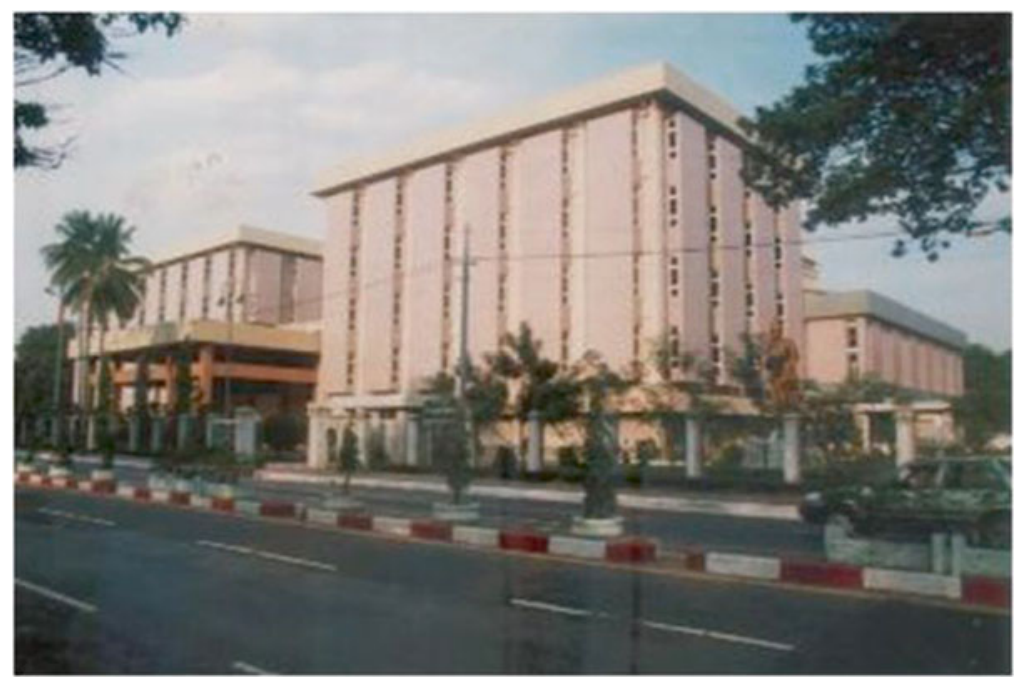

Fig. 6 National Museum (Yangon)

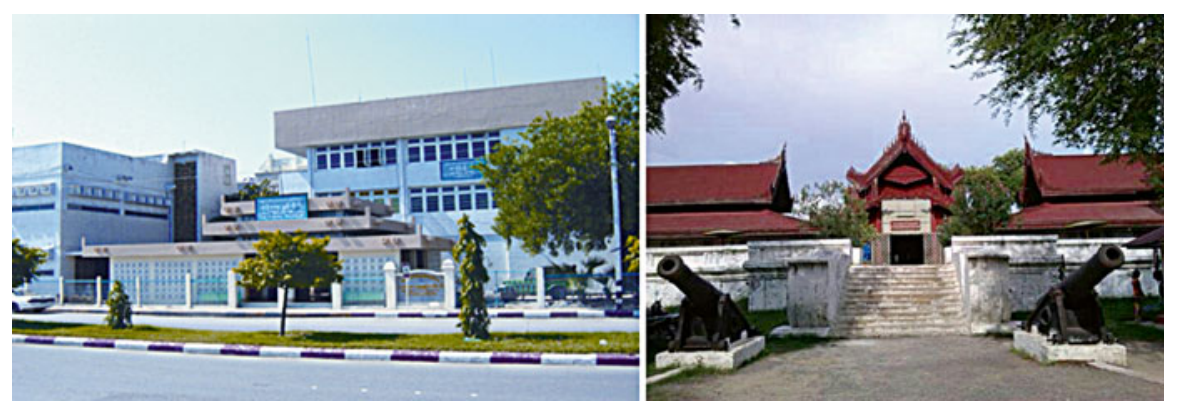

Fig. 7 Regional cultural museums in Mandalay: Mandalay Cultural Museum (left); Mandalay Palace Cultural Museum (right)

Mawlamyaing Cultural Museum (Fig. 9) became the regional museum of Mon State in 1974 (Min Naing 1978: 16).

In the Ayarwaddy Division, the history of the Pathein Cultural Museum (Fig. 10) is different from other regional museums. It started as the Bogyoke Aung San Library in 1960 and 3 years after its establishment, it was handed over to the government and became the Ayarwaddy Division Museum and Library (Min Naing 1978: 17).

Bogyoke Aung San Museum (Fig. 11), where General Aung San lived with his family from 1945 to 1949 till he was assassinated, was opened to the public in 1963. Bogyoke Aung San Residence Museum, where he was born and lived with his parents till he passed matriculation in Nat Mauk, also became a memorial museum in 1972 (Min Naing 1978: 20). 


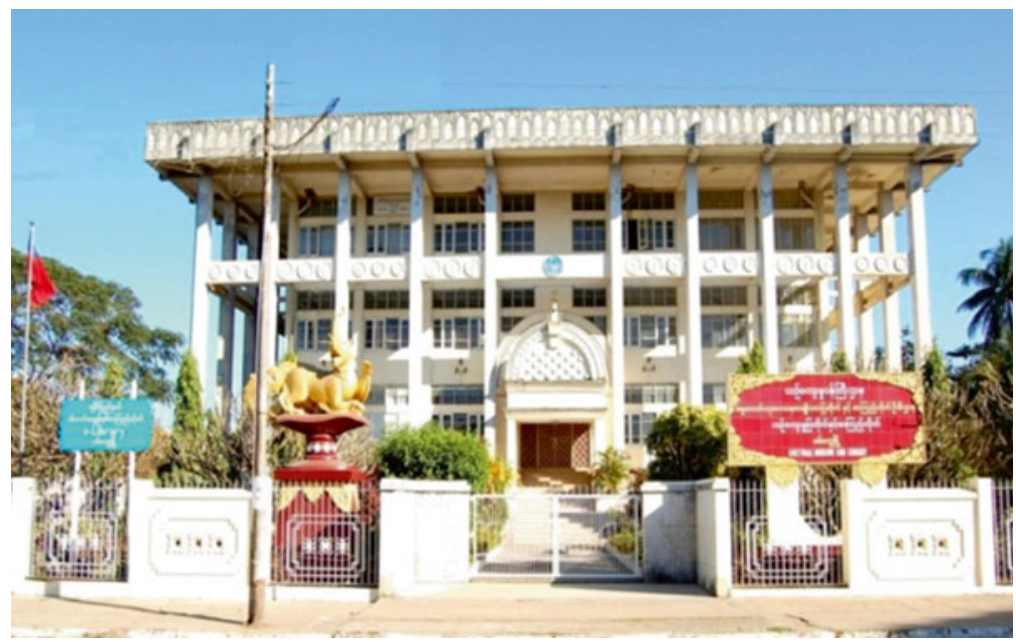

Fig. 8 Sittwe Cultural Museum

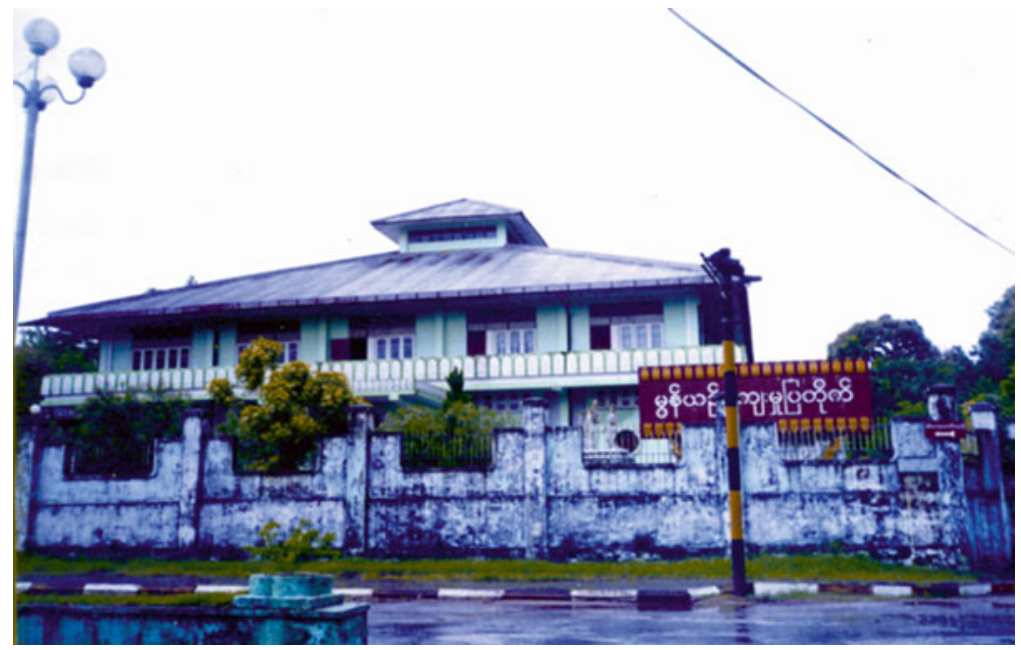

Fig. 9 Mawlamyaing Cultural Museum

Kachin State Cultural Museum (Fig. 12) in 1963 in Myitkyina, Kayah State Cultural Museum (Fig. 13) in 1967 in Loikaw, Kayin State Cultural Museum (Fig. 14) in 1955 in Hpa-an, Shan State Cultural Museum (Fig. 15) in 1956 in Taung Gyi, and Chin Special Divisional Museum (Fig. 16) in 1963 in Haka were established by their respective state governing bodies and handed over to the Ministry of Culture in 1972, and became government-run regional level cultural museums (Min Naing 1978: 17, 18). 


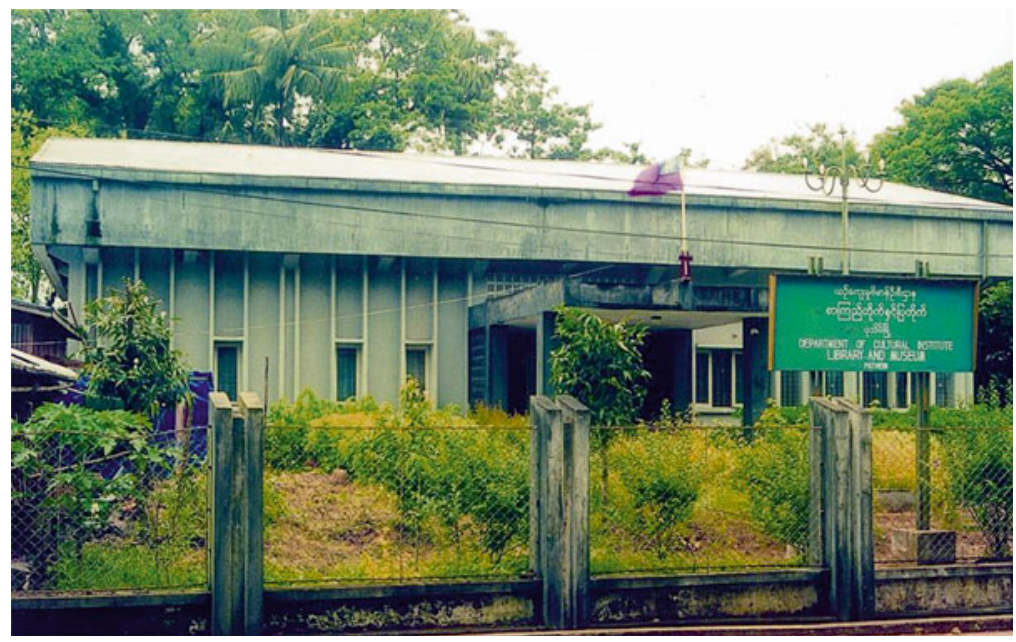

Fig. 10 Pathein Cultural Museum

Now, all of their buildings have been newly constructed in large compounds during the military government's time. Most of the regional cultural museums acquired ethnic materials together with some archaeological finds, found in their regions.

Memorial museums have collections that are different from those of regional cultural museums; they house the belongings of the person remembered, for instance, the clothing, furniture, books, utensils, and documents of General Aung San and U Thant. At present, U Thant's House Museum is also established by a private sector in Yangon.

\subsubsection{Brief History of Archaeological Museums}

Three ancient cities, namely, Sri Ksetra, Beikthano, and Halin are now in the World Heritage List. Among them, Sri Ksetra Museum (Fig. 17) is the one of earliest museums, established in the 1900s before independence.

Beikthano Archaeological Museum (Fig. 18) was established in 2008 and opened to the public in September 2009. It was built on a grand scale with the characteristics of Beikthano Pyu.

Halin Archaeological Museum was established in 2012 and opened in January 2013 as the last established archaeological museum by the Ministry of Culture to date.

There is not only Sri Ksetra, Beikthano, and Halin, but also other new site museums such as Tagaung Archaeologcial Museum (Fig. 19) (Department of Archaeology and National Museum 2014: 2). 
Fig. 11 Bogyoke Aung San Museum (Yangon)

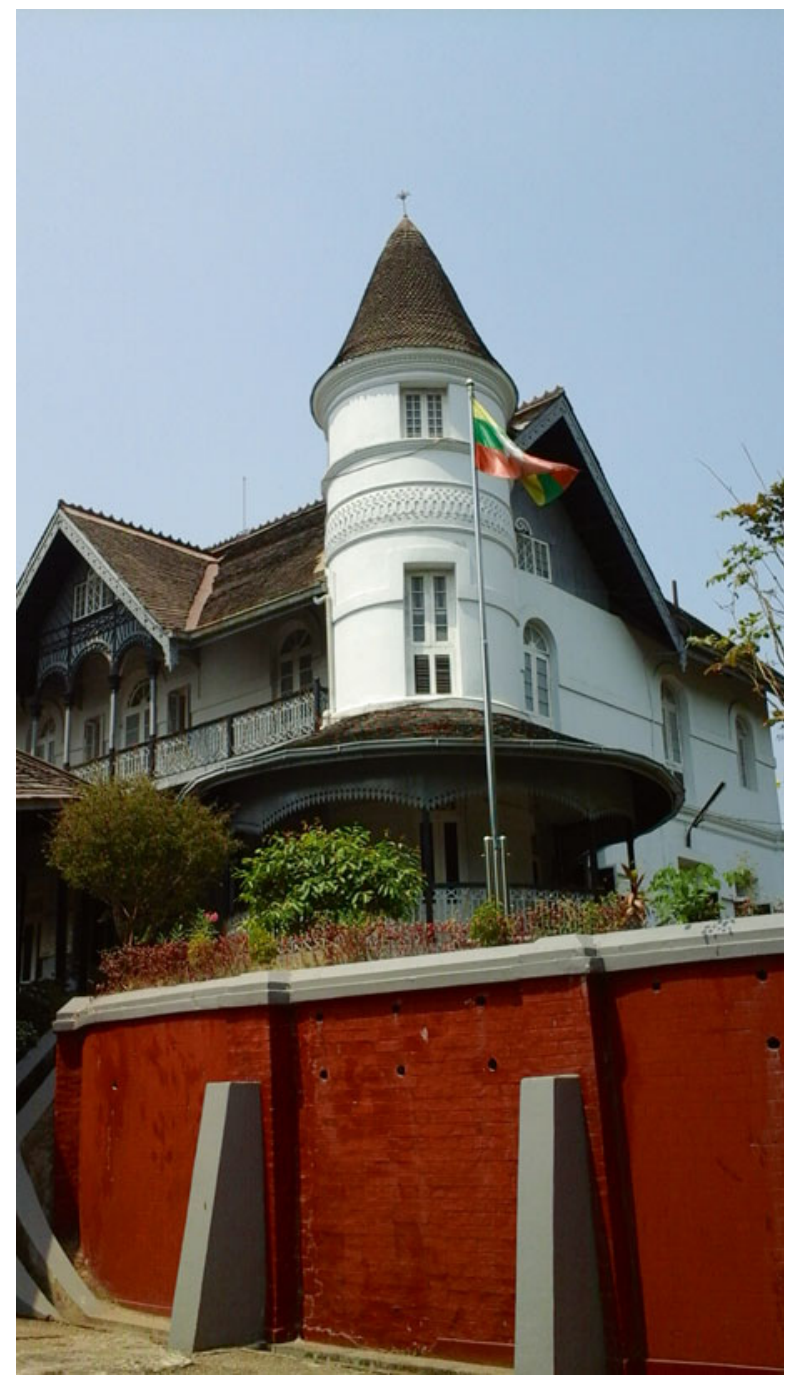

\subsubsection{Brief History of the National Museum (Nay Pyi Taw)}

After moving the capital city from Yangon to Nay Pyi Taw in 2006, the government decided to establish a new national museum in Nay Pyi Taw. The construction works started in 2011 and it is now nearly finished (Fig. 20). Display work has now started and the museum is intended to open to the public phase by phase at the end of fiscal year 2014-2015 (Department of Archaeology and National Museum 2014: 4). 


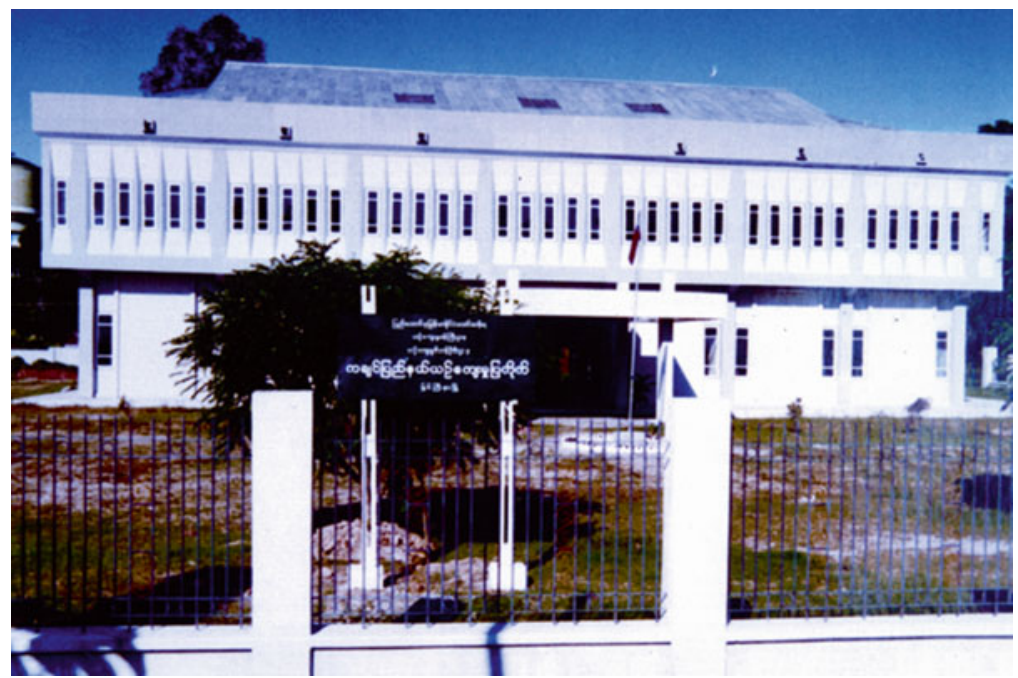

Fig. 12 Kachin State Cultural Museum

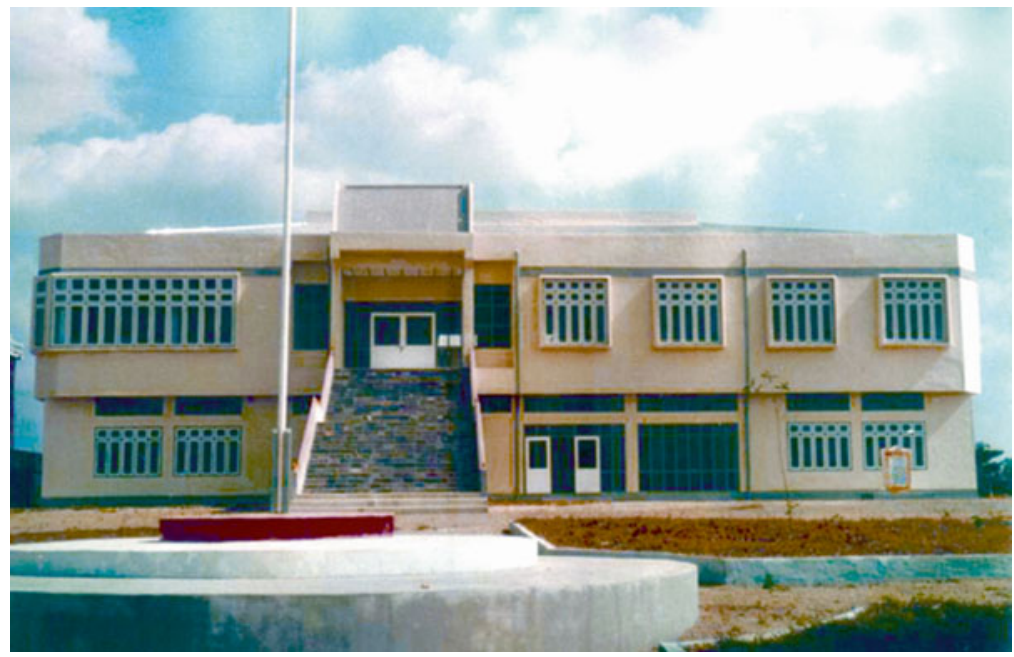

Fig. 13 Kayah State Cultural Museum

\section{Actual Perspectives on Myanmar Museums}

\subsection{Actual Perspectives on the National Museums of Yangon and Nay Pyi Taw}

In fact, the situation at the beginning of the National Museum (Yangon) can be identified from a report of Dr. Nihar-ranjanan Ray as "a poor nucleus of such a museum exists in the Jubilee Hall at the present moment, consisting of a small 


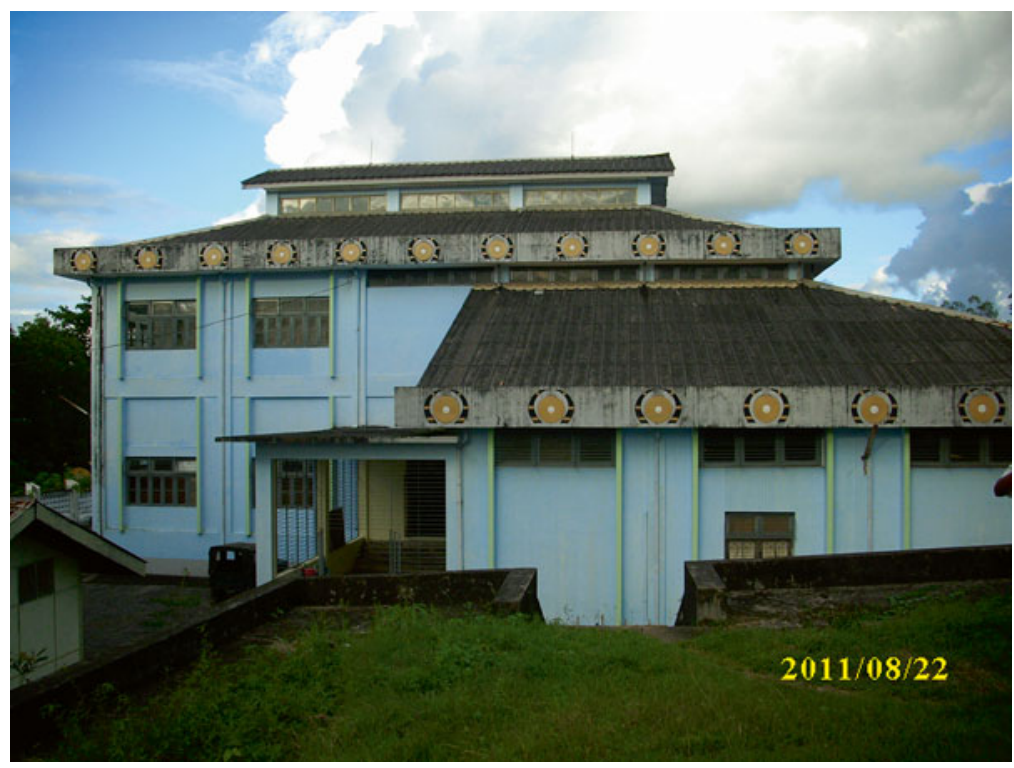

Fig. 14 Kayin State Cultural Museum

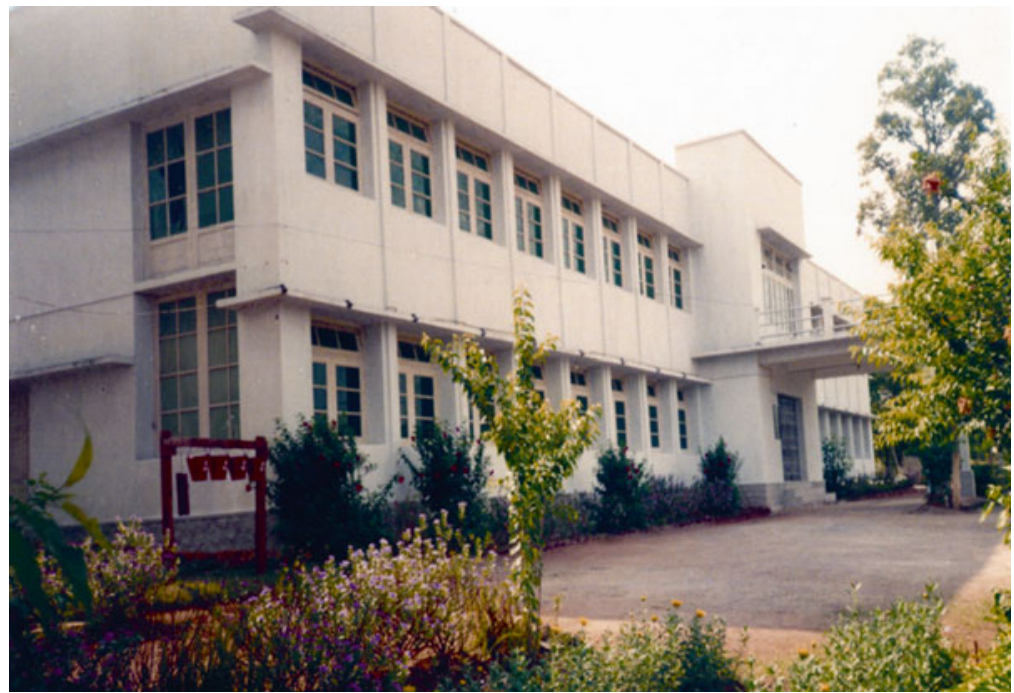

Fig. 15 Shan State Cultural Museum 


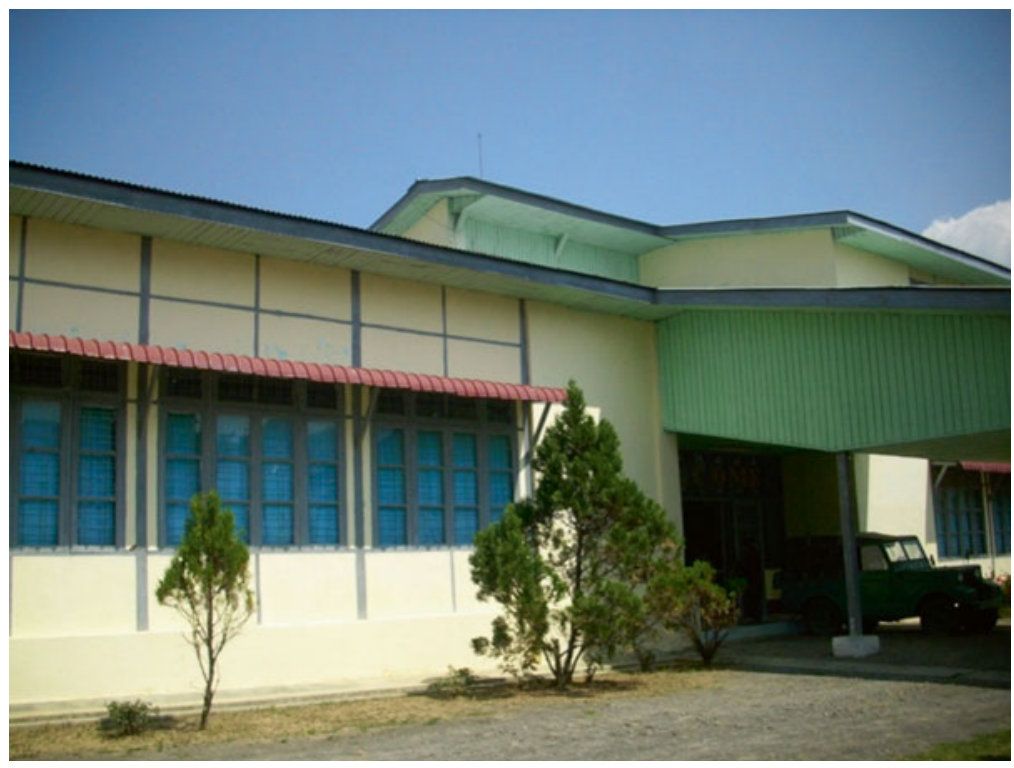

Fig. 16 Chin State Cultural Museum

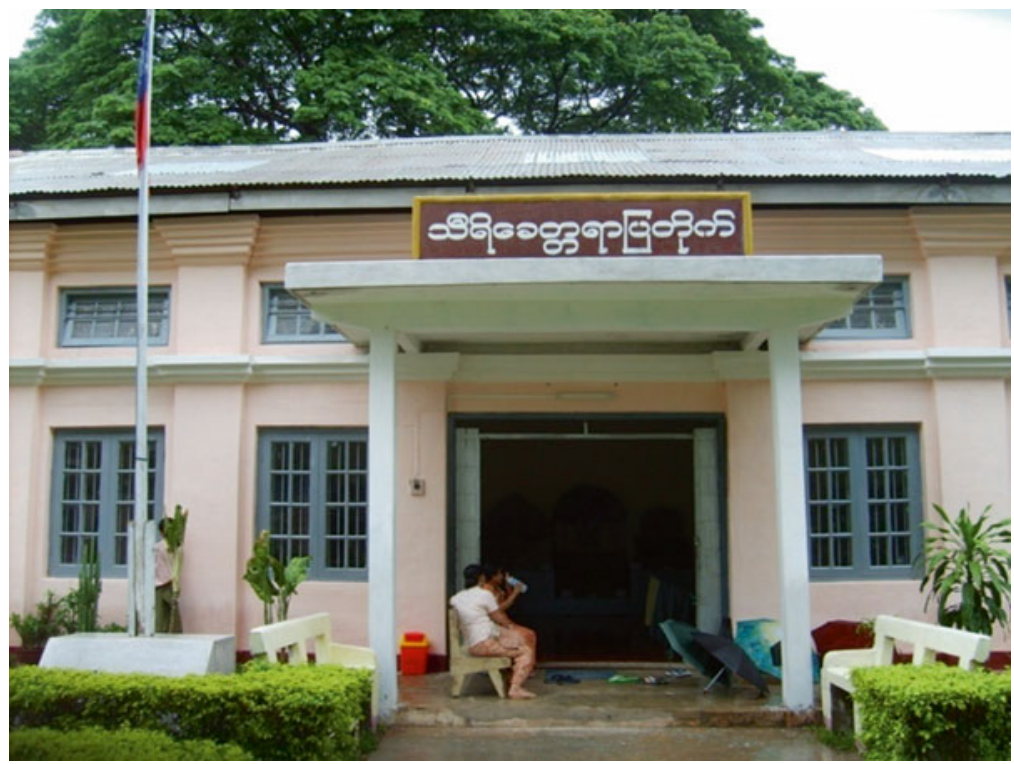

Fig. 17 Sri Ksetra Museum 


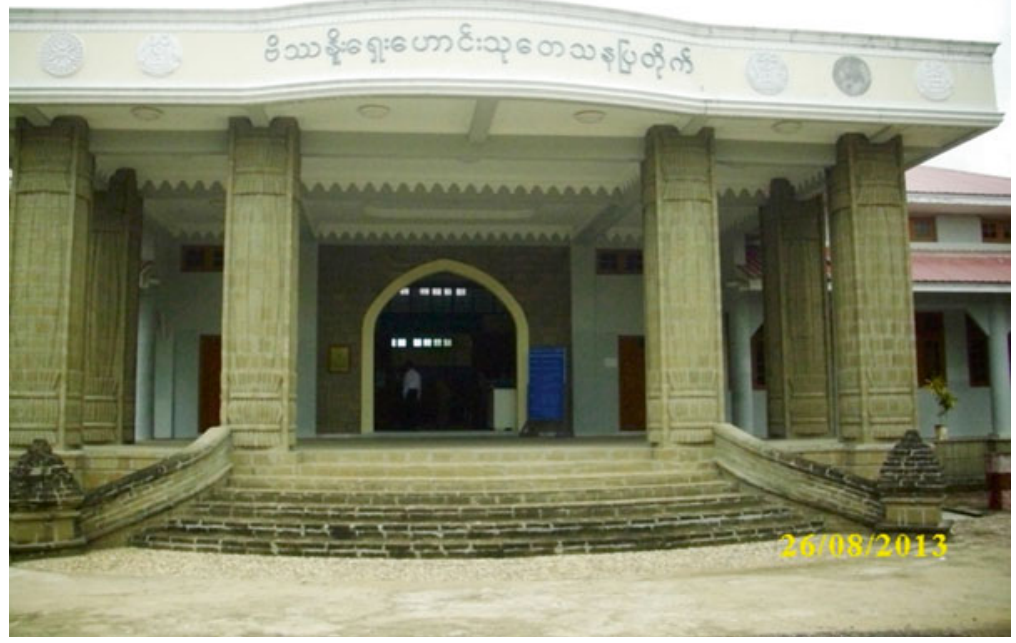

Fig. 18 Beikthano Archaeological Museum

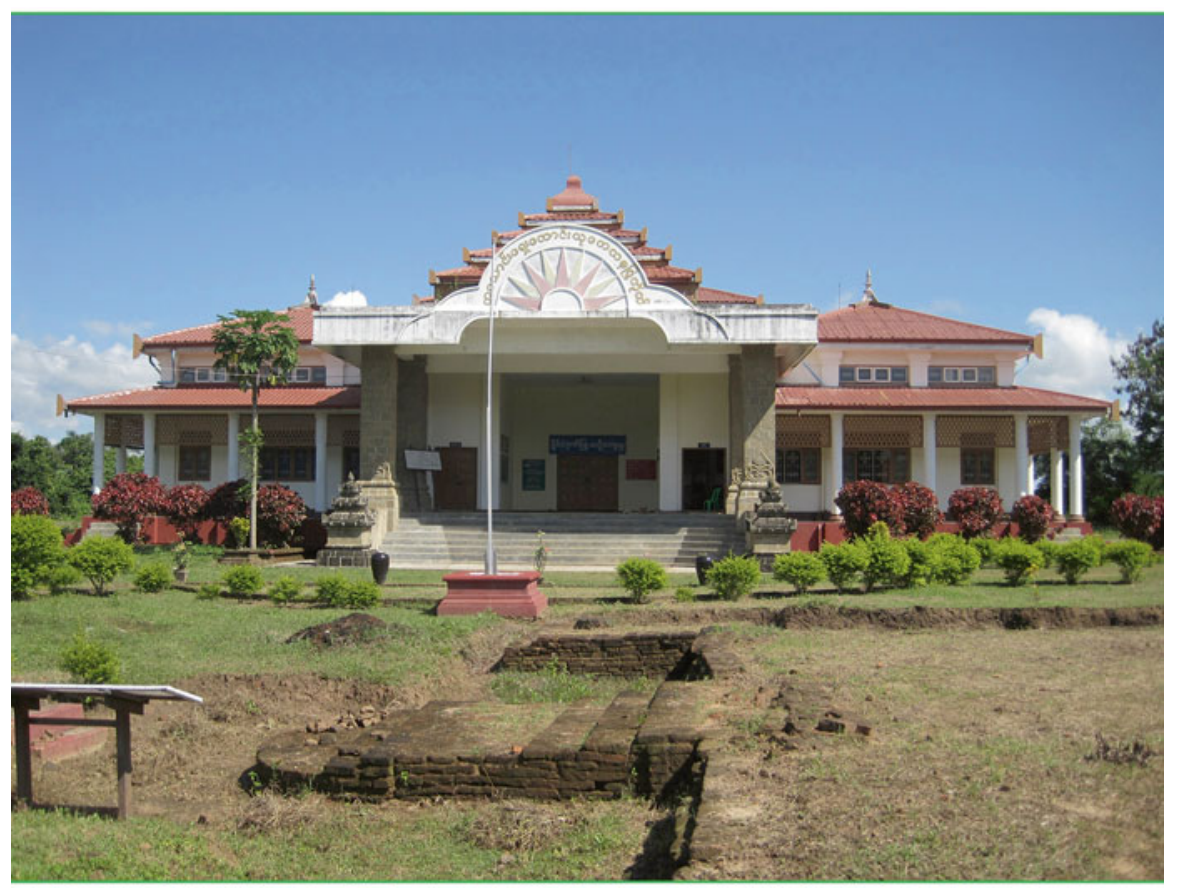

Fig. 19 Tagaung Archaeological Museum 


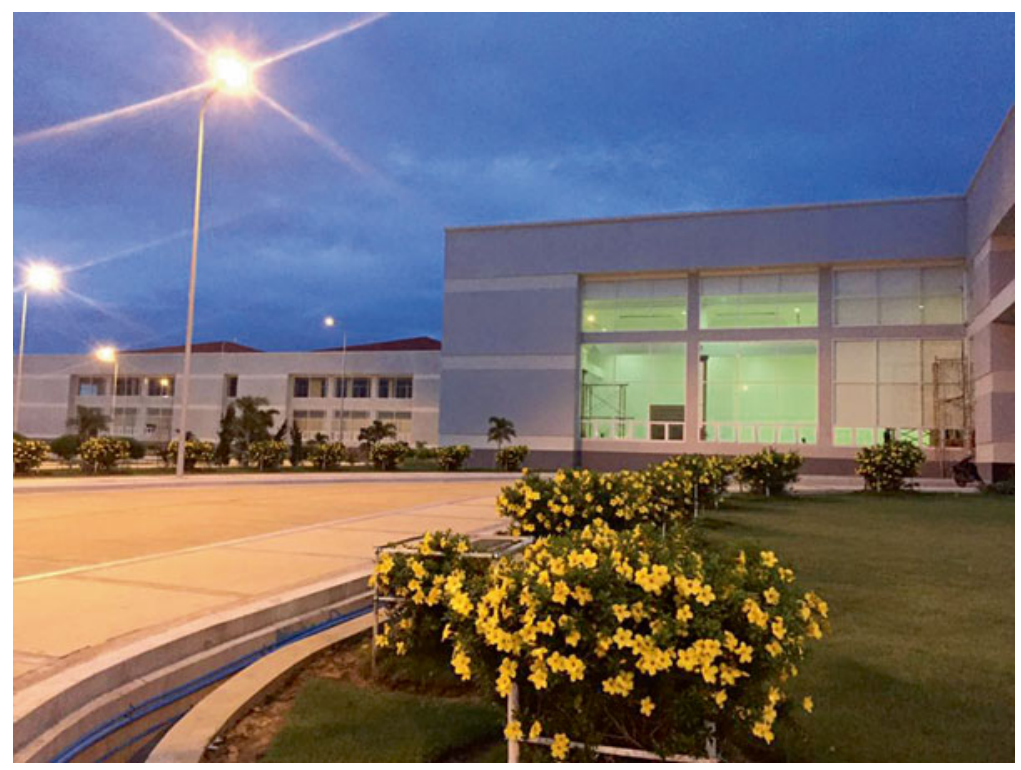

Fig. 20 National Museum (Nay Pyi Taw)

collection of objects of arts and crafts and of ethnology and archaeology. But attempts are being made to acquire representative objects of real value and a good sum has been budgeted for the current year, for the purpose." However, ancient palm leaf manuscripts and paper parchments, royal epistles and seals, musical instruments, ancient coins, royal costumes, royal furniture, ethnological items, and Myanmar traditional handicrafts were on display in different sections.

From that situation, the collections increased gradually and over 3,840 items were collected and exhibited from 1952 to 1962, one decade. In 1957, the Royal Lion Throne was moved from the President's Residence to the National Museum and exhibited there. Since 1962, the National Museum changed into a type of historical museum and exhibitions of the twentieth-century history of Myanmar and related exhibits were highlighted. In 1968, after moving to a building in Pansodan Street, the historical museum changed its type again to a national museum. In 1969, one exhibition room for culture of nationalities was extended. At that time, there were only six exhibition rooms, i.e., Royal Lion Throne and Royal Regalia, Stone Age, Pyu Period, Bagan Period, Arts and Crafts, and Performing Arts (Department of Archaeology and National Museum 1996: 4). There was also an art gallery, with the aim of establishing a new and separate national art gallery. The National Museum's collection is mostly based on donations by local people and transfers from archaeological departments.

According to this background history, the National Museum (Yangon)'s display is a combination of the themes of history, archaeology, art, and ethnology. However, because of the inappropriate architecture, historical exhibition rooms are out of sequence. Moreover, due to the lack of location space, storage areas and conservation 
areas, which are highly important, are very limited and difficult to extend. Mismanagement by the ministerial authorities has also made the National Museum smaller than before by placing other departmental branches in the same building.

But, we can conclude that "something is better than nothing," because after 25 years, the National Museum was able to move to its present place, with some space for landscaping and car parking, the likes of which it has never owned before, although the area is becoming smaller as the number of visitors is increasing. And we would also like to thank our government for having the chance to change the displays of the exhibition rooms by providing budget. We have started to implement the reform project since the 2013-2014 budget year, and the reception hall, ticket counter, and Myanmar Epigraphy and Calligraphy exhibition room are completely finished. In 2014-2015, this budget year, the Myanmar Art Gallery is nearly finished and the Myanmar Historic Period exhibition room has even changed title to "Myanmar Civilization" by adding Pyu period objects from the Myanmar Protohistoric Period exhibition room. The Myanmar Civilization exhibition room is now divided by partitions from the Myanmar Regalia exhibition room and new installation works are being undertaken.

Successful work has been rental of the audio guide system in four languages, Myanmar, English, Japanese, and Chinese, for visitors. A Japanese company (Miyashita Co. Ltd.) donated 42 sets of the audio guide system to the National Museum (Yangon).

The appearance of one new national museum in Nay Pyi Taw has been commented on by some outsiders and foreigners but it should be welcomed as a highstandard national-level museum in Myanmar. It is also now at a serious stage trying to open at least six exhibition rooms at the end of this budget year.

However, we need to change the organizational strength of both national-level museums. Another weakness is that the volunteer system cannot be practiced here like in foreign countries. All strength is mostly full-time staff, and only very few persons like cleaners and garden workers are part-time staff. The major constraint is a lack of technicians in museum function areas like exhibition and conservation. They have basic knowledge on museology through the Diploma in Museology courses and foreign short courses on general museology but are not experts in specialist areas. So, the staff needs more long-term training on particular museography subjects from developed countries.

Although the National Museum (Yangon) can stand as the leading museum in museology in Myanmar, our training courses are mostly based on theory. Because of a lack of facilities and budget constraints, Diploma in Museology classes cannot provide practical and experimental work on museography, especially in the area of conservation.

Another weak point is we cannot form any national organization on the museum community. The weakest point is we are still not a member of ICOM. 


\subsection{Actual Perspectives on Archaeological Museums, Regional Cultural Museums, and Other Types of Museum}

At the present time, almost all of the museums under the Ministry of Culture are changing their displays gradually one by one. For example, Mon State Cultural Museum (Mawlamyaing), Kayin State Cultural Museum (Hpa-an), Ayawaddy Region Cultural Museum (Pathein), Pakhangyi Archaeological Museum, Sri Ksetra Archaeological Museum, and Beikthnoe Archaeological Museum have reformed their displays within the last 5 years. At the same time, some new museums appeared such as the Halin Archaeological Museum and Northern Shan State Cultural Museum (Lashio).

Among other types of museum, many religious museums of pagoda trustees want to change their displays with the technical assistance of museum experts from the Ministry of Culture. Shwedagon Pagoda Museum in Yangon and Mahamuni Museum in Mandalay are good examples.

I am trying to help them not only with the display areas, but also with systematic documentation and staffing. However, the trustee board members began willingly to cooperate with the museum experts. This is one of the achievements. In Nay Pyi Taw, the new Upartasanti (the replica pagoda of Shwedagon Ceti) museum was established since 2010.

At the moment, the new Military Museum, Gems Museum, Planetarium, Railway Museum, the small Aquarium, National Landmark Garden, and Safari Park are open to the public in Nay Pyi Taw. In Pyin Oo Lwin, the Fossil Museum and the Butterfly Museum are being extended by the private sector. In Yangon, private museums will soon appear.

The most important weak point is the need for strong museum law and regulations on how to establish a new museum. We would welcome many new museums appearing with momentum. It shows that Myanmar local people have begun to take an interest in museums.

\section{Conclusion}

The museums not only under the Ministry of Culture, but also from other ministries and other institutions including the private sector, need to collaborate to organize one national museum organization to work together for the improvement of the Myanmar museum world. Moreover, developed nations' support and aid are welcome for Myanmar museum development. 
Open Access This chapter is distributed under the terms of the Creative Commons AttributionNonCommercial 4.0 International License (http://creativecommons.org/licenses/by-nc/4.0/), which permits any noncommercial use, duplication, adaptation, distribution and reproduction in any medium or format, as long as you give appropriate credit to the original author(s) and the source, provide a link to the Creative Commons license and indicate if changes were made.

The images or other third party material in this chapter are included in the work's Creative Commons license, unless indicated otherwise in the credit line; if such material is not included in the work's Creative Commons license and the respective action is not permitted by statutory regulation, users will need to obtain permission from the license holder to duplicate, adapt or reproduce the material.

\section{References}

Department of Archaeology and National Museum. 1996. Guide to the National Museum (Yangon). Yangon: Ministry of Culture. (In Burmese).

Department of Archaeology and National Museum. 1997. Guide to Bagan Archaeological Museum. Yangon: Ministry of Culture. (In Burmese).

Department of Archaeology and National Museum. 2014. Annual Report of the Department of Archaeology and National Museum 2013-2014. Yangon: Ministry of Culture. (In Burmese).

Department of Cultural Institute. 2000. Facts and figures on the Department of Cultural Institutes. Yangon: Ministry of Culture. (In Burmese).

Min Naing U. 1978. Guide to Myanmar museums. Yangon: Ministry of Culture. (In Burmese).

Taylor, L.F. 1924. A Burma Provincial Museum. Journal of the Burma Research Society 14(Part I): $1-12$. 